\title{
ЗНАЧЕННЯ МАРКЕРІВ ЕНДОГЕННОЇ ІНТОКСИКАЦІЇ В ПРОГНОСТИЧНІЙ ОЦІНЦІ ІШЕМІЧНО-РЕПЕРФУЗІЙНОГО СИНДРОМУ КІНЦІВКИ
}

\section{Значення маркерів ендогенної інтоксикації в прогностичній оцінці ішемічно-реперфузійного синдрому кінцівки}

\section{Н. В. Волотовська, А. А. Гудима}

Тернопільський національний медичний університет імені І. Я. Горбачевського МОЗ України

Резюме. Застосування кровоспинного джуга $є$ перевіреним засобом первинної медичної допомоги. Проте системні порушення, як і ультраструктурні в ділянці компресії, здатні суттєво погіршувати стан травмованого організму. Встановлення вираження ендогенної інтоксикації є важливим аспектом розуміння перебігу ішемічно-реперфузійного синдрому (IPC) кінцівки.

Мета дослідження - вивчити маркери ендогенної інтоксикації у сироватці крові в умовах впливу стресових чинників та їх поєднання.

Матеріали і методи. Для дослідження використано 260 білих статевозрілих щурів-самців (5,-5,5 місячя), яких поділили на 6 груп: контрольна група, ЕГ1 - моделювання ізольованого IPC кінцівки, ЕГ2 - моделювання ізольованої об'ємної крововтрати, ЕГЗ - поєднання IPC кінцівки з крововтратою, ЕГ4 - моделювання ізольованої механічної травми стегна, ЕГ5 - поєднання IPC кінцівки та механічної травми. У сироватці після завершення експерименту визначали еритоцитарний індекс інтоксикації (EII) та молекули середньої маси (MCM).

Результати. Встановлено, що кожне з експериментальних втручань призвело до підвищення вищенаведених показників. Особливістю було те, що в першу годину після декомпресії EII на тлі ізольованої крововтрати був найвищим, проте до 7 доби він знизився. При цьому в період з 1 до 3 доби включно був на рівні з Ell на тлі IPC, поєднаного $з$ механічною травмою. Найбільш виражений розвиток інтоксикаційного синдрому було виявленно у групі, де IPC поднувався з крововтратою. Так, на 3 добу показник перевищив початковий рівень у 2,1 раза $(p<0,05)$, на 14 добу залишався підвищеним, порівняно 3 контролем, - на 77,7 \% $(p<0,05)$. Також на 3 добу показник у цій групі був найвищим порівяно з аналогічними показниками в інші досліджувані періоди.

Висновки. Поєднання ішемічного-реперфузійного синдрому кінцівки з крововтратою призвело до вираженої ендогенної інтоксикації, також порушення були найбільш вираженими саме в цій групі порівняно з ізольованим впливом кожного експериментального втручання.
Significance of endogenous intoxication markers in prognosis assessment of ischemic reperfusion limb syndrome

N. V. Volotovska, A. A. Hudyma

I. Horbachevsky Ternopil National Medical University

e-mail: volotovskanv@tdmu.edu.ua

Summary. The use of hemostatic tourniquet is a proved means of primary care. However, systemic disorders, as well as ultrastructural, in the area of compression can significantly worsen the condition of the injured body. Establishing the severity of endogenous intoxication is an important aspect of understanding the course of ischemic-reperfusion syndrome (IRS) of the limb.

The aim of the study - to investigate the level of erythrocyte intoxication index (EII) in different periods of IRS development.

Materials and Methods. 260 white adult male rats were used in the experiment. They were divided into 6 groups: control, EG1 - simulation of isolated IRS of the limb), EG2 - simulation of isolated volumetric blood loss, EG3 - combination of IRS of the limb with blood loss, EG4 - simulation of isolated mechanical injury of the thigh, EG5 - combination of IRS of the limb and mechanical injury.

Results. It was found that each of the experimental interventions has led to an increase of investigated index. The peculiarity was that in the first hour after decompression Ell on the background of isolated blood loss was the highest, but by the $7^{\text {th }}$ day it has decreased. In this case, in the period from 1 to 3 days inclusive was at the level of EIl levels on the background of IRS, combined with mechanical trauma. The most expressed development of intoxication syndrome was found in the group, where IRS was combined with blood loss. Thus, on the $3^{\text {rd }}$ day - the index exceeded the initial level by 2.1 times \% $(p<0.05)$, on the $14^{\text {th }}$ day remained elevated, compared with the control - by $77.7 \%(p<0.05)$. Also, on the $3^{\text {rd }}$ day the index in this group was the highest, comparatively to other explored periods.

Conclusions. The combination of ischemic-reperfusion syndrome with blood loss led to severe endogenous intoxication, and the resulting disorders were most expressed in this group, compared with the isolated effects of each experimental intervention. 
Ключові слова: ішемія; реперфузія; крововтрата; ендогенна інтоксикація; еритроцитарнмий індекс інтоксикації; експеримент.

\section{ВСТУП}

Зміни у мембранах клітин, що виникають на тлі ендогенної інтоксикації, - це один 3 елементів успішної тактики при її розвитку [1].

Розвиток ендотоксикозу своїми наслідками впливає практично на кожну систему організму [2-4], здатний таким чином викликати різноманітні ускладнення [5] і виникає унаслідок особливого впливу на організм токсичних речовин ендогенного чи екзогенного походження [6]. Значущість маркерів ендогенної інтоксикації важко переоцінити і це доводять численні інорормаційні джерела [7].

Ендогенна інтоксикація і наступне перевантаження екскреції білкових продуктів розпаду, пов'язане 3 нею, має багато причин $[8,9]$. За даними інорормаційних джерел, є багато індикаторів ендогенної інтоксикації, серед найпоширеніших еритроцитарний індекс інтоксикації (EII) та молекули середньої маси [6], які зазвичай фрормуються і в здоровому організмі $[10,11]$. Проте з настанням ектремальних умов, що порушують нормальну життєдіяльність, вони набувають властивостей вторинних токсинів і здатні суттєво порушувати перебіг основного патогічного процесу [12-14]. Також у розвитку ендогенної інтоксикації велика роль належить і порушенню імунобіологічного захисту [15], а саме десріциту фракторів як клітинного, так і гуморального імунітету.

Зрозуміло, що зміни, які виникають в крові, $€$ неспецифрічними для багатьох патофрізіологічних процесів, проте за своєю суттю дуже добре відображають процеси, що відбуваються в цілому організмі. У даній статті ми вирішили зробити акцент саме на першому показнику еритроцитарного індексу інтоксикації, оскільки в порівнювані групі - це ішемічно-реперфузійний синдром і вплив на нього крововтрати, яка сама по собі викликає гіпоксію [16], і запускає оксидативний стрес [17], як майбутній чинник активації ПОЛ [18], який також ізольовано може бути індуковано ішемією-реперфузією.

Проте даних, які би висвітлювали та порівнювали ступінь прояву саме цього показника ендогенної інтоксикації на тлі ішемічно-реперфузійного синдрому кінцівки, практично немає.

Метою дослідження було вивчити маркери ендогенної інтоксикації у сироватці крові в умовах впливу стресових чинників та їх поєднання.

\section{МАТЕРІАЛИ I МЕТОДИ}

Експеримент виконано на 260 білих нелінійних щурах-самцях (5-5,5 місяця), яких утримували в
Key words: ischemia; reperfusion; blood loss; endogenous intoxication; erythrocyte intoxication index; experiment.

традиційних умовах віварію. Для досягнення мети було сорормовано 6 дослідних груп: контрольна група (КГ), ЕГ1 - накладання кровоспинного джгута на стегно протягом 2 год (ізольована ішемія-реперфузія); ЕГ2 - моделювання крововтрати; ЕГЗ - поєднання ішемічно-реперорузії із крововтратою; ЕГ4 - нанесення на стегнову кістку механічної травми 3 метою моделювання перелому за допомогою апарата щП-1; ЕГ5 - поєднання ішемії-реперфуззії з механічною травмою.

Експеримент здійснено в умовах тіопенталнатрієвого знеболювання (40 мг/кг) 3 дотриманням загальних правил і положень Європейської конвенції про захист хребетних тварин, які використовуються для дослідних та інших наукових цілей (Страсбург, 1986), Резолюції Першого Національного конгресу біоетики (Київ, 2011) та Закону Міністерства здоров'я України № 690 від 23 вересня 2009 р. [19]. Так, ішемічно-реперфузійний синдром моделювали, наклавши на верхнюю 1/3 стегна смужку гумового джгута шириною 1 см, розраховуючи силу натиску під контролем маркування, нанесенного на джгут. Залишали на 2 год, після чого тварину звільняли. Для моделювання крововтрати здійснювали забір крові зі стегнової вени в об'ємі 40 \% від об'єму циркулюючої крові. Тварин виводили 3 експерименту через 1 год після декомпресії чи інших втручань, на 1; 3; 7 і 14 доби після травми шляхом тотальної кровотечі 3 серця.

Визначення еритроцитарного індексу інтоксикації (EII, \%) здійснювали за методом, який базується на уявленні, що еритроцит є адсорбентом, тобто його еритроцитарна мембрана здатна поглинати і пропускати забарвлені речовини [20].

Отриманий цифровий матеріал був оброблений методом варіаційної статистики з використанням t-критерію Стьюдента. Розраховували середні арифметичні величини (М), похибки середніх арифрметичних $(\mathrm{m})$, коефіцієнти варіації, а також середні квадратичні відхилення. Зміни вважали достовірними при $\mathrm{p} \leq 0,05$. У рисунках та таблицях рівень значимості вказували тільки для достовірних результатів. Відмінності між середніми величинами вважали достовірними за вірогідності альтернативної гіпотези не менше ніж 0,95 [21].

Для розрахунків використовували комп'ютерну програму Microsoft Excel XP (USA). Всі отримані результати були оброблені методом варіаційної статистики з використанням однофакторного дисперсійного аналізу ANOVA за допомогою програми Originpro 7.5 .
ISSN 2706-6282(print)

ISSN 2706-6290(online)
Вісник медичних і біологічних досліджень

Bulletin of Medical and Biological Research
$3(5), 2020$ 


\section{РЕЗУЛЬТАТИ Й ОБГОВОРЕННЯ}

Динаміка наростання патогенних впливів, пов'язаних зі збільшенням концентрації величини EII у нелікованих тварин, загалом $€$ схожою до результатів, отриманих групою вчених, які вивчали IPC кінцівки у нелікованих та лікованих тварин [22-24].

Розвиток ендогенної інтоксикації в умовах даного експериментального втручання $\epsilon$ однією із ланок замкненого хибного кола в мультиорганному ураженні, зокрема це було доведено як нашими попередніми дослідженнями, так і групою інших вчених [24-26]. Дослідженнями встановлено, що в умовах моделювання ізольованого ішемічнореперфузійного синдрому, ізольованої травми та поєднання цих втручань між собою призводили до підвищення рівня ендогенної інтоксикації. При порівнянні з даними КГ у всі дослідні періоди (за винятком 1 год в ЕГ1) величина EII була статистично достовірно вищою.

Так, як видно з рисунка 1 і таблиці, величина EII істотно зростала на тлі модифрікацій IPC і його поєднань $з$ крововтратою та травмою. Вже через 1 год на тлі ізольованого ІРС у ЕГ1 вже через 1 год, на 1 і 3 доби після декмпресії даний показник був вищим від КГ відповідно на 17,9 \% ( $<<0,05)$, на $32,3 \%(p<0,05)$ і на $32,8 \%(p<0,05)$. На 7 добу показник перевищив рівень КГ на $17,4 \%(p<0,05)$. На тлі ізольованої крововтрати у ЕГ2 через 1 год після втручання показник перевищив рівень КГ на 44,4 \% $(\mathrm{p}<0,05)$. На 1 і 3 доби показник був вищим за дані КГ на $59 \%(p<0,05)$ і на 57,9 \% відповідно $(p<0,05)$, а також продовжував залишатися статистично достовірно підвищеним і на 7 та 14 доби, порівняно 3 КГ, - на $28 \%(p<0,05)$ і на 25,6 \% $(p<0,05)$. У ЕГЗ на тлі IPC, поєднаного з крововтратою, показник через 1 год після декопресії перевищував КГ на 40,9\% $(p<0,05)$. На 1 і 3 доби він активно зростав і був вищим, порівяно з КГ, на 91,3 \% (p<0,05) і в 2,1 раза $(p<0,05)$, а на 7 і 14 добу - на 92,9\% $(p<0,05)$ і на $77,7 \%(p<0,05)$ вищим за дані КГ.

Як видно з таблиці і рисунка 2, на тлі ізольованої травми у ЕГ4 через 1 год після травми показник був вищим за дані КГ на 28,3 \% (p<0,05), на 1; 3 i 7 доби - був вищим на 36,5 \% ( $p<0,05)$, на 45,2 \% $(p<0,05)$ і на $28,7 \%(p<0,05)$. Аналогічною, тільки більш вираженою, динаміка була на тлі механічної травми, поєднаної з IPC у ЕГ5 - через 1 год після декомпресії показник перевищив рівень КГ на $20,9 \%(p<0,05)$; на 1; 3 і 7 доби після втручання був вищим від КГ відповідно на 51,5 \% (p<0,05), на $58,4 \%(p<0,05)$ і на $37,4 \%(p<0,05)$.

Незалежно від тяжкості втручання, у більшості випадків динаміка змін досліджуваного показника мала певні закономірності: до 3 доби показник зростав (за винятком ЕГ2), а на 7 добу - знижувався. Так, на тлі ізольованого IPC у ЕГ1 пік збільшення EII припав на 3 добу, коли показник був вищим за дані 1-ї після декомпресії години на 12,6 \% $(p<0,05)$. На 7 добу показник був нижчим від рівня 1 доби на $11,3 \%(p<0,05)$ і на $11,6 \%(p<0,05)$ відповідно. На 14 добу показник знизився, порівняно з даними 1; 3 і 7 діб, на 21,3 \% ( $<<0,05)$, на 21,6 \% $(p<0,05)$ і на $11,3 \%(p<0,05)$ відповідно.

Динаміка в ЕГ2 була такою: Ell був найвищим на 1 і 3 доби й статистично достовірно перевищував рівень 1 год на 10,1\% $(p<0,05)$ і на 9,3\%. На 7 добу показник знизився, порівняно 31 год, на $11,3 \%(p<0,05)$, а порівняно 31 і 3 добами, - на

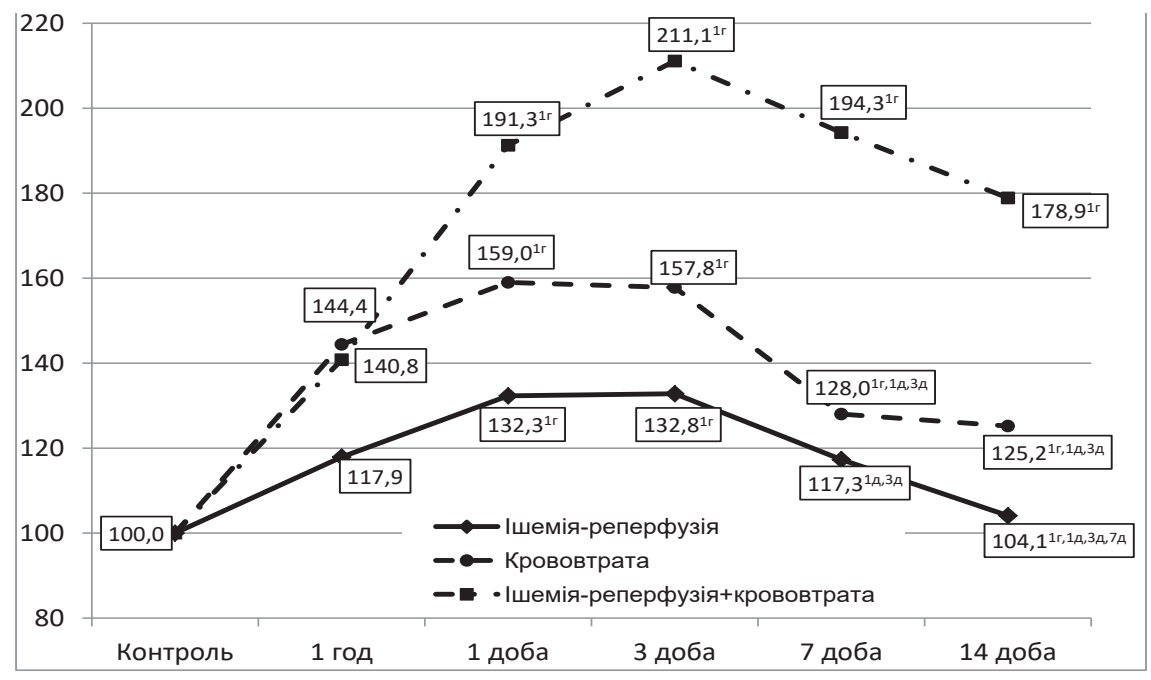

група

Рис. 1. Динаміка вмісту еритоцитарного індексу інтоксикації (у відсотках до рівня контрольної групи) після ішемії-реперфузії кінцівки та крововтрати.

Примітка. Тут і на інших рисунках: 1г,1д,зд,7д - відмінності стосовно 1 год, 1; 3 і 7 діб спостереження статистично вірогідні, р<0,05. 
Таблиця. Еритоцитарний індекс інтоксикації після ішемії-реперфузії кінцівки, скелетної травми та крововтрати (Me (LQ; UQ)) - медіана (нижній і верхній квартилі)

\begin{tabular}{|c|c|c|c|c|c|}
\hline \multirow{2}{*}{ Дослідна група } & \multicolumn{5}{|c|}{ Термін реперфузійного періоду } \\
\hline & 1 год & 1 доба & 3 доба & 7 доба & 14 доба \\
\hline \multicolumn{6}{|c|}{ Контроль=42,93 $(40,62 ; 46,70)(n=10)$} \\
\hline $\begin{array}{l}\text { ЕГ1 } \\
\text { Ішемія-реперфузія }\end{array}$ & $\begin{array}{c}50,60^{\star} \\
(48,13 ; 51,58) \\
(n=10)\end{array}$ & $\begin{array}{c}56,79^{*} \\
(55,34 ; 59,56) \\
(n=10)\end{array}$ & $\begin{array}{c}57,00^{\star} \\
(53,59 ; 58,20) \\
(n=10)\end{array}$ & $\begin{array}{c}50,38^{\star} \\
(47,16 ; 51,25) \\
(n=10)\end{array}$ & $\begin{array}{c}44,69 \\
(42,43 ; 46,33) \\
(n=10)\end{array}$ \\
\hline $\begin{array}{l}\text { ЕГ2 } \\
\text { Крововтрата }\end{array}$ & $\begin{array}{c}62,00^{\star} \\
(59,5 ; 62,93) \\
(n=7)\end{array}$ & $\begin{array}{c}68,26^{\star} \\
(63,72 ; 72,27) \\
(n=7)\end{array}$ & $\begin{array}{c}67,77^{\star} \\
(64,94 ; 69,35) \\
(n=6)\end{array}$ & $\begin{array}{c}54,97^{\star} \\
(50,12 ; 57,20) \\
(n=7)\end{array}$ & $\begin{array}{c}53,73^{*} \\
(49,53 ; 56,28) \\
(n=7)\end{array}$ \\
\hline $\begin{array}{l}\text { ЕГЗ } \\
\text { Ішемія-реперфузія+ } \\
\text { крововтрата }\end{array}$ & $\begin{array}{c}60,47^{*} \\
(55,32 ; 64,89) \\
(n=6)\end{array}$ & $\begin{array}{c}82,14^{\star} \\
(71,77 ; 87,96) \\
(n=6)\end{array}$ & $\begin{array}{c}90,00^{*} \\
(77,78 ; 95,94) \\
(n=6)\end{array}$ & $\begin{array}{c}82,83^{*} \\
(76,93 ; 88,46) \\
(n=6)\end{array}$ & $\begin{array}{c}76,27^{\star} \\
(68,75 ; 77,88) \\
(n=5)\end{array}$ \\
\hline$p_{1-3}$ & $<0,05$ & $<0,05$ & $<0,05$ & $<0,05$ & $<0,05$ \\
\hline$p_{2-3}$ & $>0,05$ & $>0,05$ & $<0,05$ & $<0,05$ & $<0,05$ \\
\hline $\begin{array}{l}\text { ЕГ4 } \\
\text { Травма }\end{array}$ & $\begin{array}{c}55,10^{*} \\
(51,66 ; 58,73) \\
(n=10)\end{array}$ & $\begin{array}{c}58,62^{*} \\
(54,03 ; 65,25) \\
(n=10)\end{array}$ & $\begin{array}{c}62,35^{\star} \\
(60,00 ; 66,21) \\
(n=10)\end{array}$ & $\begin{array}{c}55,23^{*} \\
(53,53 ; 56,23) \\
(n=10)\end{array}$ & $\begin{array}{c}48,42 \\
(45,02 ; 49,59) \\
(n=10)\end{array}$ \\
\hline $\begin{array}{l}\text { ЕГ5 } \\
\text { Ішемія-реперфузія+ } \\
\text { травма } \\
\end{array}$ & $\begin{array}{c}51,91^{*} \\
(50,46 ; 61,08) \\
(n=9)\end{array}$ & $\begin{array}{c}65,05^{*} \\
(63,12 ; 67,02) \\
(n=9) \\
\end{array}$ & $\begin{array}{c}67,99^{\star} \\
(65,83 ; 72,29) \\
(n=8) \\
\end{array}$ & $\begin{array}{c}59,00^{\star} \\
(58,02 ; 63,40) \\
(n=9) \\
\end{array}$ & $\begin{array}{c}51,04 \\
(46,57 ; 53,44) \\
(n=9) \\
\end{array}$ \\
\hline$p_{1-5}$ & $>0,05$ & $<0,05$ & $<0,05$ & $<0,05$ & $>0,05$ \\
\hline$p_{4-5}$ & $>0,05$ & $>0,05$ & $>0,05$ & $<0,05$ & $>0,05$ \\
\hline
\end{tabular}

Примітки: 1) * - відмінності стосовно контрольної групи статистично вірогідні (p<0,05);

2) $p_{1-3}$ - вірогідність відмінностей стосовно дослідних груп 1 і 3;

2) $\mathrm{p}_{2-3}$ - вірогідність відмінностей стосовно дослідних груп 2 і 3 ;

3) $p_{1-5}$ - вірогідність відмінностей стосовно дослідних груп 1 i 5

4) $\mathrm{p}_{4-5}$ - вірогідність відмінностей стосовно дослідних груп 4 і 5.

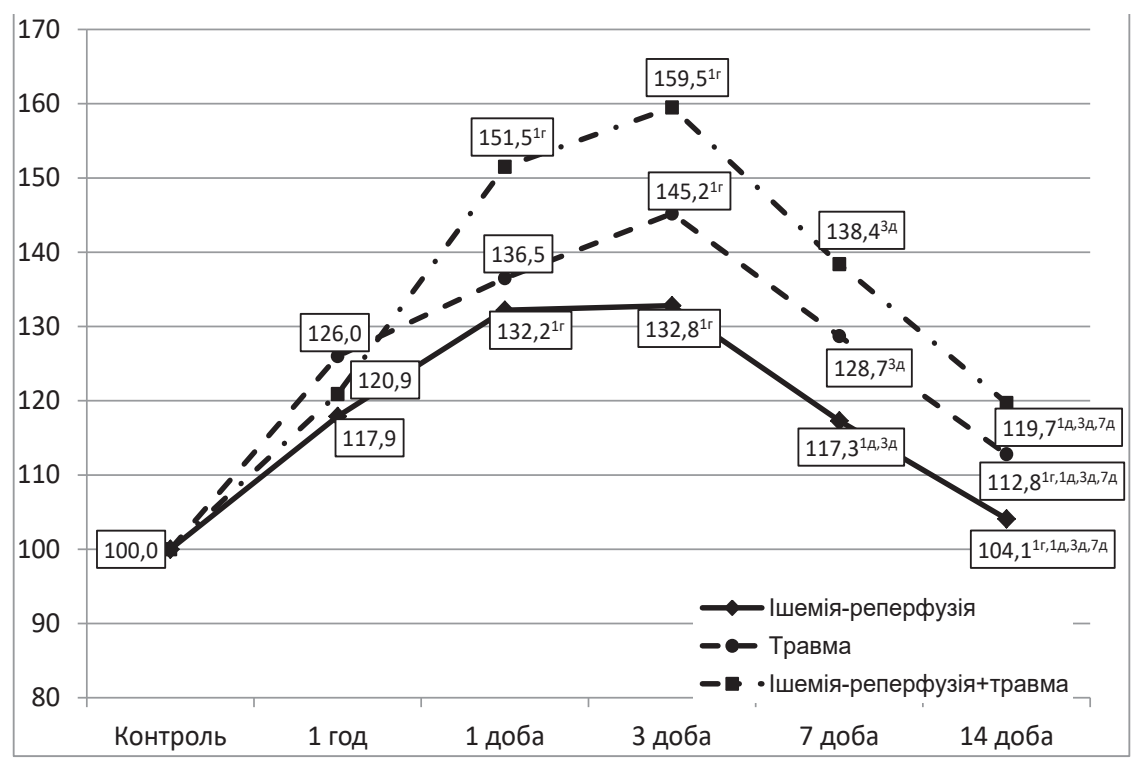

група

Рис. 2. Динаміка вмісту еритоцитарного індексу інтоксикації (у відсотках до рівня контрольної групи) після ішемії-реперфузії кінцівки та скелетної травми. 
$19,5 \%(p<0,05)$ і на 18,9 \% $(p<0,05)$ відповідно. На 14 добу показник був нижчим від рівня 1 год на 13,3 \% ( $p<0,05)$, порівняно 31 і 3 добами, - на 21,3 $\%(p<0,05)$ і на 20,7 \% $(p<0,05)$ відповідно.

Динаміка в ЕГЗ на тлі IPC, поєднаного з крововтратою, була наступною: на 1 добу показник був статистично достовірно вищим, порівняно з 1 год, - на 35,8 \% (p<0,05), а на 3 добу перевищив рівень 1 год на 48,8 \% ( $p<0,05)$. НА 7 і 14 доби рівень EII перевищив рівень 1 год на $37 \%(p<0,05)$ і на $26,1 \%(p<0,05)$ відповідно.

що стосується EII на тлі ізольованої травми в ЕГ4, то на 3 добу показник перевищив рівень 1 год на 13,2\% (p<0,05), а на 7 добу вже став нижчим від 3 доби на 11,4 \% (p<0,05). На 14 добу показник знизився ще більше, зокрема, порівняно з рівнем 1 год, 1; 3 і 7 діб відповідно на 12,1 \% ( $p<0,05)$, на $17,4 \%(p<0,05)$, на 22,3\% $(p<0,05)$ і на $1,3 \%$ $(\mathrm{p}<0,05)$. Таким чином, пік виявився на 3 добу, а завершально досліджуваний показник так і не знизився до рівня контрольної групи.

На тлі IPC, поєднаного 3 травмою у ЕГ5, на 1 добу показник EII був вищим за рівень 1 год на 25,3 $\%(p<0,05)$. На 3 добу, яка як і в попередній групі виявилася критичною, показник перевищив рівень 1 год на $31 \%(p<0,05)$. На 7 добу Ell був нижчим за рівень 3 доби на 13,2 \% (p<0,05), а на 14 добу продовжував знижуватися, хоч і не досяг початкового рівня, та був нижчим за рівень 1; 3 і 7 діб відповідно на 21,5 \% $(p<0,05)$, на 24,9\% $(p<0,05)$ і на 13,5\% $(p<0,05)$.

Аналіз зміни величини досліджуваного показника в експериментальній сироватці статевозрілих щурів встановив, що у групах з різним ступенем тяжкості втручання були наступні відмінності, які вказували на значущість впливу ІШС кінцівки. Так, через 1 год рівень EII був найбільш вираженим на тлі ізольованої крововтрати в ЕГ2. Очевидно, причиною цього міг стати високий рівень гіпоксії і оксидативний стрес, що закономірно розвинулися на цьому тлі. Зрештою, підтвердженням цього може стати ряд публікацій про патогенез гемічної гіпоксії $[16,27]$. Також показник ElI був високим і в ЕГ3, таким чином перевищивши показник ЕГ1 на 19,5\% ( $<<0,05)$, і також будучи нижчим за дані ЕГ2 на 2,5 \% (p>0,05). Також у ЕГ5 через 1 год показник був вищим за ЕГ1 на 1,6 \% (p>0,05), і був нижчим, порівняно з ЕГ 4 , на $5,8 \%$ (p>0,05).

На 1 добу після втручання показник Ell у ЕГЗ був статистично достовірно вищим за дані ЕГ1 на $44,6 \%(p<0,05)$ і вищим від ЕГ2 на 20,3 \% ( $>>0,05)$. А у ЕГ5 показник перевищив дані ЕГ1 на 14,5 \% $(p<0,05)$. На 3 добу показник ЕГЗ був вищим за дані в ЕГ1 і ЕГ2 на 57,9 \% $(p<0,05)$ і на $32,8 \%$ $(p<0,05)$ відповідно, а показник ЕГ5 був вищим від ЕГ1 і ЕГ4 на $19,3 \%(p<0,05)$ і на $9 \%(p>0,05)$ відповідно. На 7 добу показник ЕГЗ перевищив статистично достовірно дані ЕГ1 і ЕГ2 на 64,4 \% $(p<0,05)$ i на 50,7 \% (p<0,05). У ЕГ5 показник перевищив дані ЕГ1 і ЕГ4 на 17,1 \% $(p<0,05)$ і на 6,8 \% $(p<0,05)$. На 14 добу показник EII в ЕГЗ був вищим, порівняно 3 даними ЕГ1 і ЕГ2, на 70,7 \% $(p<0,05)$ і на $42 \%$ ( $p<0,05)$, а також був вищим за ЕГ1 і ЕГ4 на 14,2 \% $(p>0,05)$ і на 5,4 \% (p>0,05) відповідно.

Узагальнюючи отримані результати досліджень, можна зробити висновок, що навіть застосування кровоспинного джгута терміном на 2 год має статистично достовірно підтверджений патологічний вплив на весь організм. Саме це важливо врахувавувати при наданні лікувально-медикаментозної допомоги, якщо крововтрата була масивною або є ускладнювальні фрактори за типом поєднаної чи комбінованої травми.

Як видно із даних усіх експериментальних груп, навіть ізольований IPC сам по собі здатний підвищувати рівень Ell. Щодо патогенезу на тлі ізольованої крововтрати, то гостра крововтрата результується зростанням загальної протеолітичної активності в крові [28], а чим вираженіша крововтрата, тим вищою є ця активність, що загалом теж узгоджується із нашими результатами досліджень [29]. Одним із рушійних фракторів, що запускає EII на тлі крововтрати, є надмірна реалізація в кровоносне русло катехоламінів, що активує анаеробний гліколіз, а це, у свою чергу, сприяє розвитку дистрофрічних змін у внутрішніх орнанах [30]. Таким чином, дані експериментальні досліження вказують на порушення регулювання та роботи детоксикаційної системи чи внаслідок дисбалансу між окремими її ланками. Це узгоджується із загальноприйнятим визначенням ендогенної інтоксикації, як такої, що розвивається за загальними принципами, незалежно від першопричини, що їй сприяла.

\section{ВИСНОВКИ}

Встановлено, що кожне 3 експериментальних втручань призвело до підвищення вищенаведених показників. Особливістю було те, що в першу годину Ell на тлі ізольованої крововтрати був найвищим, проте до 7 доби він знизився. При цьому в період 31 до 3 доби включно був на рівні 3 Ell на тлі IPC, поєднаного з механічною травмою. Найбільш виражений розвиток інтоксикаційного синдрому було виявленно у групі, де IPC поднувався 3 крововтратою. Так, на 3 добу показник перевищив початковий рівень у 2,1 раза ( $<<0,05)$, на 14 добу залишався підвищеним, порівняно з контрольною групою, - на 77,7 \% $(p<0,05)$. Також на 3 добу показник у цій групі був найвищим порівяно 3 аналогічними показниками в інші досліджувані періоди. Таким чином, поєднання ішемічногорепердузійного синдрому кінцівки 3 крововтратою призвело до вираженої ендогенної інтоксикації, також спричинені порушення були найбільш вираженими саме в цій групі, порівняно з ізольованим впливом кожного експертиментального втручання. 


\section{СПИСОК ЛІТЕРАТУРИ}

1. Значение мембраностабилизирующей способности антиоксидантов в их детоксикационном эфрфекте / С. Г. Анаскин, Т. И. Власова, Г. А. Шевалаев [и др.] // Современные проблемы науки и образования. - 2012. - № 6.

URL: http://www.science-education.ru/ru/article/ view?id=7372 (дата обращения: 04.08.2020).

2. Григ Н. І. Ендогенна інтоксикація як фрактор ризику в комплексному лікуванні генералізованого пародонтиту / Н. І. Григ // Современная стоматогия. - 2015. - № 1. C. 28-31.

3. Новий погляд на питання діагностики ендогенної інтоксикації у хворих з опіковою травмою / В. С. Савчин, л. Р. Остап'юк, А. С. Волошиновський, Т. С. Малий // Шпитальна хірургія. Журнал імені Л. Я. Ковальчука. 2019. - № 1. - C. 20-24.

4. Реперфузионное эндотоксиновое повреждение органа зрения в эксперименте / Г. А. Дроздова, А. Ф. Самигуллина, Е. А. Нургалеева, А. А. Сорокин // Казанский медицинский журнал. - 2015. - Т. 96, № 5. - С. 811-814.

5. Буката В. В. Вплив ендогенної інтоксикації на розвиток ускладнень після оперативного лікування хворих зі спайковою кишковою непрохідністю / В. В. Буката // Вісник наукових досліджень. - 2017. - № 3. - С. 69-73. DOI 10.11603/2415-8798.2017.3.8068

6. Шмойлов Д. К. Патогенетическая роль эндогенной интоксикации /Д. К. Шмойлов, И. З. Каримов, Т. Н. Одинець// Лабораторна діагностика. - 2012. - № 2(60). - С. 65-69.

7. Єгудіна $€$. Д. Клініко-патогентична значущість синдрому ендогенної інтоксикації при системній склеродермії / Є. Д. Єгудіна, В. Я. Мікукстс, О.В.Синяченко // Вісник наукових досліджень. - 2017. - № 1. - С. 28-32. DOI 10. 11603/2415-8798.2017.1.7338

8. Clark W. R. Uremic Toxins and their relation to Dialysis efficacy / W. R. Clark, N. L. Dehghani, V. Narsimhan, R. Claudio // Blood Purification. - 2019. - No. 48. - P. 299314. DOI: $10.1159 / 000502331$.

9. Эндогенная интоксикация в патогенезе нефропатий / Э. А. Юрьева, В. С. Сухоруков, Е.С. Воздвиженский [и др.] // Клиническая лабораторная диагностика. - 2015. - № 3. - С. 22-25.

10. Лабораторная диагностика синдрома эндогенной интоксикации : метод. рекоменд. / В. М. Аксенова, В. Ф. Кузнецов, В. В. Щекотов, А. П. Щекотова. - Пермь : ПГМА, 2005. - 39 с.

11. Тамарова Э. Р. Исследования распростаненности соматической патологии у больных пародонтитом / Э. Р. Тамарова, А. Р, Мавзютов // Укр. мед. часопис : наук.практ. загальномед. часопис. - 2014. - № 4. - С. 186-192.

12. Діагностичне значення лабораторних показників ендогенної інтоксакації при негоспітальній пневмонії / С. М. Андрейчин, Н. А. Бількечив, Т. Ю. Чернець [та ін.] // Здобутки клінічної і експериментальної медицини. 2017. - № 3. - С. 18-21.

13. Матолич У. Д. Клініко-лабораторні аспекти синдрому ендогенної інтоксикації у хворих на абсцес та фрлегмони щелепно-лицевої ділянки / У. Д. Матолич, Лє. Є. Лаповець, І. М. Горгота // Новини стоматології. 2013. - № 4 (77). - С. 16-20.

14. Морфосризиологический анализ плазмы крови при эндогенной интоксикации / Л. М. Обухова, М. В. Ведунова, К. Н. Конторщикова, Н. А. Добротина // Вестник
Нижегородского университета им. Н. И. Лобачевского. 2007. - № 6. - С. 104-107.

15. Мустасрина Ж. Г. Интегральные гематологические показатели в оценке иммунологической реактивности у больных с офртальмолопатологией / Ж. Г. Мустафина, Ю. С. Крамаренко, В. Ю. Кобцева // Клин. лаб. диагностика. - 1999. - № 5. - С. 47-48.

16. Дука Т. І. Вплив гемічної гіпоксії на динаміку концентрації ГФКБ у структурах мозку та сироватці крові щурів / Т. В. Дука, В. І. Чорна // Вісник Дніпропетровського університету. Біологія. Екологія. - 2016. - № 24(1). C. $143-150$.

17. Гуніна Л. М. Метаболічні аспекти впливу фрізичних навантажень: оксидативний стрес та адаптація / Л. М. Гуніна, О. В. Носач // Український журнал клінічної та лабораторної медицини. - 2012. - Вип. 7, № 4. - С. 237-243.

18. Дружина Л. О. Метаболіти оксидативного стресу як предиктори променевих і канцерогенних ризиків / Л. О. Дружина, Е. А. Дьоміна, Л. І. Маковецька // Онкологія. - 2019. - Т. 21, № 2. - С. 170-175.

19. Закон Міністерства здоров'я України № 690. URL: https://zakon.rada.gov.ua/laws/show/z1010-09\#

20. Способ диагностики эндогенной интоксикации / А. А. Тогайбаев, А. В. Кургузкин, И. В. Рикун, Р. М. Карибжанова // Лабораторное дело. - 1988. - № 9. - С. 22-24.

21. Лапач С. Н. Статистические методы в медикобиологических исследованиях с использованием Excel / С. Н. Лапач, А. В. Чубенко, П. Н. Бабич - К.: Морион, 2000. -320 c.

22. Крилюк В. О. Розвиток синдрому ендогенної інтоксикації за умов поєднаної травми органів черевної порожнини на фоні гіповолемічного шоку та реперфузійного синдрому кінцівки / В. О. Крилюк, Г. Ю. Цимбалюк // Вісник наукових досліджень. - 2018. - № 2. C. 145-149. DOI 10.11603/2415-8798.2018.2.9205

23. Серватович А. М. Динаміка показників ендогенної інтоксикації в період пізніх проявів травматичної хвороби після краніоскелетної травми та ефективність їх корекції фрітозбором / А. М. Серватович, А. А. Гудима // Здобутки клдінічної і експериментальної медицини. 2016. - № 1. - С. 58-63.

24. Близнюк Р. В. Осоюдтвості фрормування синдрому ендогенної інтоксикації та динаміка вмісту імунних комплексів у ранній період після нанесення політравми В тварин із хронічним гепатитом / Р. В. Близнюк, А. А. Гудима, О. Б. Сван // Вісник наукових досліджень. - 2015. - № 3. - С. 116-118.

25. Волотовська Н. В. Особливості гепаторенальної реакції на тлі експериментального ішемічно-реперфузійного синдрому / Н. В. Волотовська, А. А. Гудима // Вісник проблем біології і медицини. - 2020. - Вип. 2(156). C. $86-91$.

26. Морфофризиологический анализ плазмы крови при эндогенной интоксикации / Л. М. Обухова, М. В. Ведунова, К. Н. Конторщикова, Н. А. Добротина // Вестник ННГУ. - 2007. - № 6. URL: https://cyberleninka.ru/article/n/ morfofiziologicheskiy-analiz-plazmy-krovi-pri-endogennoyintoksikatsii (дата обращения: 04.08.2020).

27. Маньковська І. М. Мітохондрії як мішень інтервальної гіпоксії / І. М. Маньковська, Т. В. Серебровська // Фізіологічний журнал. - 2014. - Т. 60, № 6. - C. 75-87. 
28. Прийма О. В. Лейкоцитарні чинники інтоксикації при гострій крововтраті і методи її лікування / О. Б. Прийма // Шпитальна хірургія. - 2009. - № 2. - С. 77-79.

29. Прийма О. Б. Клиническое значение определения общей протеолитической активности крови при кровотечениях / О. Б. Прийма, В. Р. Билас // Кли-

\section{REFERENCES}

1. Anaskin SG, Vlasova TI, Shevalaev GA, Vlasova VP, Potyanova IV, Suvorova LA, Zelentsov PV. [The value of membrane stabilizing ability of antioxidants in their detoxifying effect]. Sovremennye problemy nauki i obrazovaniya. 2012;6. Available from: http://www.scienceeducation.ru/ru/article/view?id=7372. Russian.

2. Grig NI. [Endogenous intoxication as a risk factor in the complex treatment of generalized periodontitis]. Sovremennaya stomatogiya. 2015;1: 28-31. Ukrainian.

3.SavchinVS, OstapiukLR, VoloshynovskyiAS., MalyiTS. [A new look at the diagnosis of endogenous intoxication in patients with burns]. Shpytalna khirurhiia. Zhurnal imeni L. Ya. Kovalchuka. 2019;1: 20-4. Ukrainian.

4. Drozdova GA, Samigullina AF, Nurgaleeva EA, Sorokin AA.[Reperfusion endotoxin damage to the organ of vision in the experiment]. Kazanskiy meditsinskiy zhurnal. 2015;96(5): 811-4. Russian.

5. Bukata VV. [The effect of endogenous intoxication on the development of complications after surgical treatment of patients with adhesive intestinal obstruction]. Visnyk naukovykh doslidzhen. 2017;3: 69-73. Ukrainian.

DOI: 10.11603/2415-8798.2017.3.8068.

6. Shmoylov DK, Karimov IZ, Odinets TN. [Pathogenetic role of endogenous intoxication]. Laboratorna diahnostyka. 2012;2(60): 65-9. Russian.

7. Yehudina YeD, Mikuksts Vla, Syniachenko OV. [Clinical and pathogenic significance of endogenous intoxication syndrome in systemic scleroderma]. Visnyk naukovykh doslidzhen. 2017;1: 28-32. Ukrainian.

DOI: 10. 11603/2415-8798.2017.1.7338.

8. Clark WR, Dehghani NL, Narsimhan V, Claudio R. Uremic Toxins and their relation to Dialysis efficacy. Blood Purif. 2019;48: 299-314. DOI: 10.1159/000502331.

9. Yurieva EA, Sukhorukov VS, Vozdvizhenskaya ES, Novikova NN, Dlin VV. [Endogenous intoxication in the pathogenesis of nephropathy]. Klinich lab diagnostika. 2015;3: 22-5. Russian.

10. Koryukina IP, Aksenova VM, Kuznetsov VF, Schekotov VV, Schekotova AP. Laboratory diagnosis of endogenous intoxication syndrome: guidelines. [Лабораторная диагностика синдрома эндогенной интоксикации : метод. рекоменд.] Perm: PGMA; 2005. Russian.

11. Tamarova ЭR, Mavziutov AR. [Studies of the prevalence of somatic pathology in patients with periodontitis]. Ukr med chasopys: nauk-prakt zahalnomed chasopys. 2014;4: 186-92. Russian.

12. Andreichyn SM., Bilkechyv NA, Chernets Tlu, Vereshchahina Nla, Kavetska NA, Ruda MM, Yarema NZ, Hanberher II, Kucher SV. [Diagnostic value of laboratory indicators of endogenous intoxication in community-acquired pneumonia]. Zdobutky klinichnoi i eksperymentalnoi medytsyny. 2017;3: 18-21. Ukrainian. ническая лабораторная дагностика. - 1995. - № 1. C. $17-18$

30. Терещенко И. П. Роль системы нейтрофильниых гранулоцитов в фоормировании особенностей развития патологических процессов / И. П. Терещенко, А. П. Кашулина // Патологическая фризиология и экспериментальная терапия. - 1993. - № 4. - С. 56-60.

13. Matolych UD, Lapovets Lle, Horhota IM. [Clinical and laboratory aspects of endogenous intoxication syndrome in patients with abscess and phlegmon of the maxillofacial area]. Novyny stomatolohii. 2013;4(77): 16-20. Ukrainian.

14. Obukhova LM, Vedunova MV, Kontorschikova KN, Dobrotina NA. [Morphophysiological analysis of blood plass ma in endogenous intoxication]. Vestnik Nizhegorodskogo universiteta im. N. I. Lobachevskogo.. 2007;6: 104-7. Russian.

15. Mustafina ZhG, Kramarenko YuS, Kobtseva VYu. [Integral hematological parameters in the assessment of immunological reactivity in patients with ophthalmopathology]. Klin lab diagnostika. 1999;5: 47-8. Russian.

16. Duka TI, Chorna BI. [Effect of hemic hypoxia on the dynamics of the GFAP concentrations in the structures of the brain and blood serum of rats]. Visn Dnipropetr univer biol ekol. 2016;24(1): 143-50. Ukrainian.

17. Hunina LM, Nosach OV. [Metabolic aspects of the impact of physical activity: oxidative stress and adaptation]. Ukrainskyi zhurnal klinichnoi ta laboratornoi medytsyny. 2012;7(4): 237-43. Ukrainian.

18. Druzhyna LO, Domina EA, Makovetska LI. [Metabolites of oxidative stress as predictors of radiation and carcinogenic risks]. Onkolohiia. 2019;21(2): 170-5. Ukrainian.

19. [Law of the Ministry of Health of Ukraine No. 690].

Available from: https://zakon.rada.gov.ua/laws/show/ z1010-09\#Text. Ukrainian.

20. Togaybaev AA, Kurguzkin AV, Rikun IV, Karibzhaz nova RM. [A method for diagnosing endogenous intoxicas tion]. Laboratornoe delo. 1988;9: 22-4. Russian

21. Lapach SN, Chubenko AV, Babich PN. Statistical methods in biomedical research using [Excel. Статистические методы в медико-биологических исследованиях с использованием Excel] Kyiv: Morion, 2000. Russian

22. Kryliuk VO, Tsymbaliuk Hlu. [Development of endogenous intoxication syndrome under conditions of combined abdominal injury on the background of hypovolemic shock and reperfusion syndrome of the limb]. Visnyk naukovykh doslidzhen. 2018;2: 145-9. Ukrainian. DOI : 10.11603/24158798.2018.2.9205/

23. Servatovych AM, Hudyma AA. [Dynamics of endogenous intoxication in the period of late manifestations of traumatic disease after cranioskeletal injury and the effectiveness of their correction by phytocomixture]. Zdobutky klinichnoi i eksperymentalnoi medytsyny. 2016;1: 58-63. Ukrainian.

24. Blyzniuk RV. Svan OB. [Features of the formation of endogenous intoxication syndrome and the dynamics of the content of immune complexes in the early period after polytrauma in animals with chronic hepatitis]. Visnyk naukovykh doslidzhen. 2105;3: 116-8. Ukrainian. 
25. Volotovska NV, Hudyma AA. [Features of hepatorenal reaction on the background of experimental ischemicreperfusion syndrome]. Visnyk problem biolohii i medytsyny. 2020;2(156): 86-91. Ukrainian.

26. Obuhova LM, Vedunova MV, Kontorschikova KN, Dobrotina NA. [Morphophysiological analysis of blood plasma in endogenous intoxication]. Vestnik NNGU. 2007;6. Available from: https://cyberleninka.ru/article/n/ morfofiziologicheskiy-analiz-plazmy-krovi-pri-endogennoyintoksikatsii. Russian.

27. Mankovska IM, Serebrovska TV. [Mitochondria as a target of interval hypoxia]. Fiziol zhurn 2014;60(6): 75-87. Ukrainian.
28. Pryima OV. [Leukocyte factors of intoxication in acute blood loss and methods of its treatment]. Shpytalna khirurhiia. 2009;2: 77-9. Ukrainian.

29. Priyma OV, Bilas VR. [Clinical significance of determining the total proteolytic activity of blood during bleeding]. Klinicheskaya laboratornaya dagnostika. 1995;1: 17-8. Russian.

30. Tereschenko IP, Kashulina AP. [Role of the system of neutrophilic granulocytes in the formation of the peculiarities of the development of pathological processes]. Pat fiziol i eksper terapiya. 1993;4: 56-60. Russian.

Отримано 11.08.20 